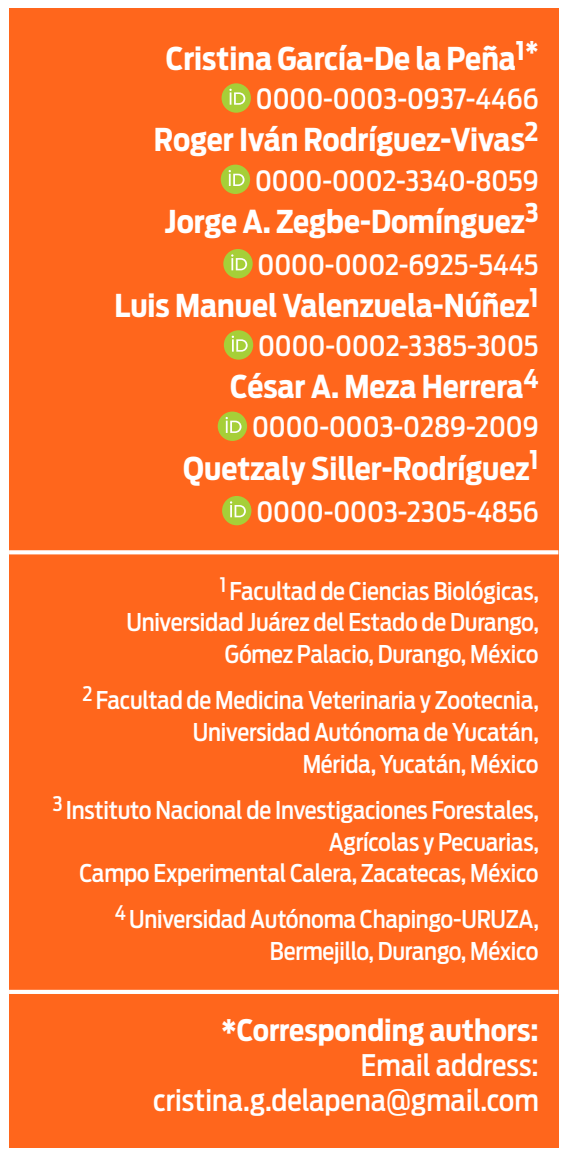

Accepted: 2019-03-25 Published: 2020-06-24

Additional information and declarations can be found on page 7

@C) Copyright 2020 Cristina García-De la Peña et al. open access $\boldsymbol{\odot}$

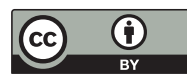

Distributed under Creative Commons CC-BY 4.0

\title{
Blood cell morphometry of wild Gopherus flavomarginatus (Bolson tortoises) in the Chihuahuan desert
}

\begin{abstract}
Morphometric characteristics of blood cells were examined in 44 (16 males, 28 females) Bolson tortoises (Gopherus flavomarginatus) in Mapimí, Mexico. Blood samples were drawn from the subcarapacial vein, and smear stains were used to differentiate and measure the diameter and surface area of cells. Mature and polychromatophilic erythrocytes were identified, as well as five types of leukocytes (lymphocytes, heterophils, eosinophils, basophils and monocytes), and thrombocytes. The shape and color of G. flavomarginatus blood cells were similar to those reported for the $G$. agassizii, and $G$. polyphemus species. Blood cell sizes fitted related data from other reptile species. The information generated in this study can help monitor the health status of $G$. flavomarginatus individuals in the wild, thus advancing efforts to protect this endangered species.
\end{abstract}

Keywords: Chelonia; Erythrocyte; Leukocyte; Thrombocyte; Desert

\section{Cite this as:}

García-De la Peña C, Rodríguez-Vivas RI, Zegbe-Domínguez JA, Valenzuela-Núñez LM, Meza Herrera CA, Siller-Rodríguez QK. Blood cell morphometry of wild Gopherus flavomarginatus (Bolson tortoises) in the Chihuahuan desert. Veterinaria México OA. 2020;7(2). doi: 10.22201/fmvz.24486760e.2020.2.676. 


\section{Introduction}

Analysis of the cellular component of blood is a common technique for evaluating the health status of wild animals. ${ }^{1,2}$ In tortoises, conditions such as anemia, leukemia, inflammation and allergy are associated with changes in blood cell values.3,4 While cell morphometry of numerous terrestrial, semiaquatic and marine tortoises has been previously described, ${ }^{5-7}$ there are still species of great ecological importance that are yet to be characterized.

Gopherus flavomarginatus is an endemic Mexican tortoise, considered to be the largest terrestrial chelonian in North America, with a carapace length of up to $40 \mathrm{~cm} .^{8}$ This species is listed as being in danger of extinction by the Official Mexican Standard $059^{9}$ and as critically endangered by the IUCN red list. ${ }^{10}$ The geographic distribution of this species is restricted to the Mapimí Bolson in the Mexican Chihuahuan desert, and has a protected status within the Mapimí Biosphere Reserve. ${ }^{11}$ Turtles of the genus Gopherus are key organisms for the ecosystems in which they live since they are herbivors performing crucial functions in seed dispersal. ${ }^{12}$ Moreover, the deep burrows that they excavate provide shelter for at least 300 invertebrate and 60 vertebrate species. ${ }^{13,14}$

The conservation efforts towards the $G$. flavomarginatus tortoise demand a better knowledge of its biology and health status. The present study aimed to determine the blood cell morphometry in this species, to provide information that may advance health monitoring, treatment and other protection strategies.

\section{Methods}

\section{Study area}

The Mapimí Biosphere Reserve covers an area of 342388 ha that includes part of the states of Chihuahua, Coahuila and Durango in Mexico $\left(26^{\circ} 00^{\prime}\right.$ and $26^{\circ} 10^{\prime} \mathrm{N}$ and $104^{\circ} 10^{\prime}$ and $103^{\circ} 20^{\prime} \mathrm{W}$ ). The climate is very arid, semi-warm BWhw(e), with an average annual temperature of $25.5^{\circ} \mathrm{C}$ and summer rains. ${ }^{15}$ The predominant vegetation is rosette and microphile scrubs, as well as halophyte, and gypsophila plants. ${ }^{16}$

\section{Field work}

From May 2015 to September 2017, forty-four individuals of the G. flavomarginatus species were captured within the Mapimí Biosphere Reserve. Blood samples were drawn from the subcarapacial vein following the USFWS protocol (Figure 1). ${ }^{17}$ Prior to sampling, the puncture area was cleaned with a cotton swab dipped in alcohol. A $3 \mathrm{~mL}$ syringe with a $23 \times 25 \mathrm{~mm}$ gauge needle was then used to extract one milliliter of blood. Samples were subsequently placed in $6 \mathrm{~mL}$ BD Vacutainer ${ }^{\circledR}$ tubes with lithium heparin and stored in a cooler at approximately $4{ }^{\circ} \mathrm{C}$ until processed. Gender was recorded for each captured tortoise considering a flat plastron, short tail, and absence of glands under the chin for females, and a concave plastron, longer tail and presence of glands under the chin for males. ${ }^{18}$ Health of all individuals was determined by established protocols 17,19 before their release at the site of capture. 


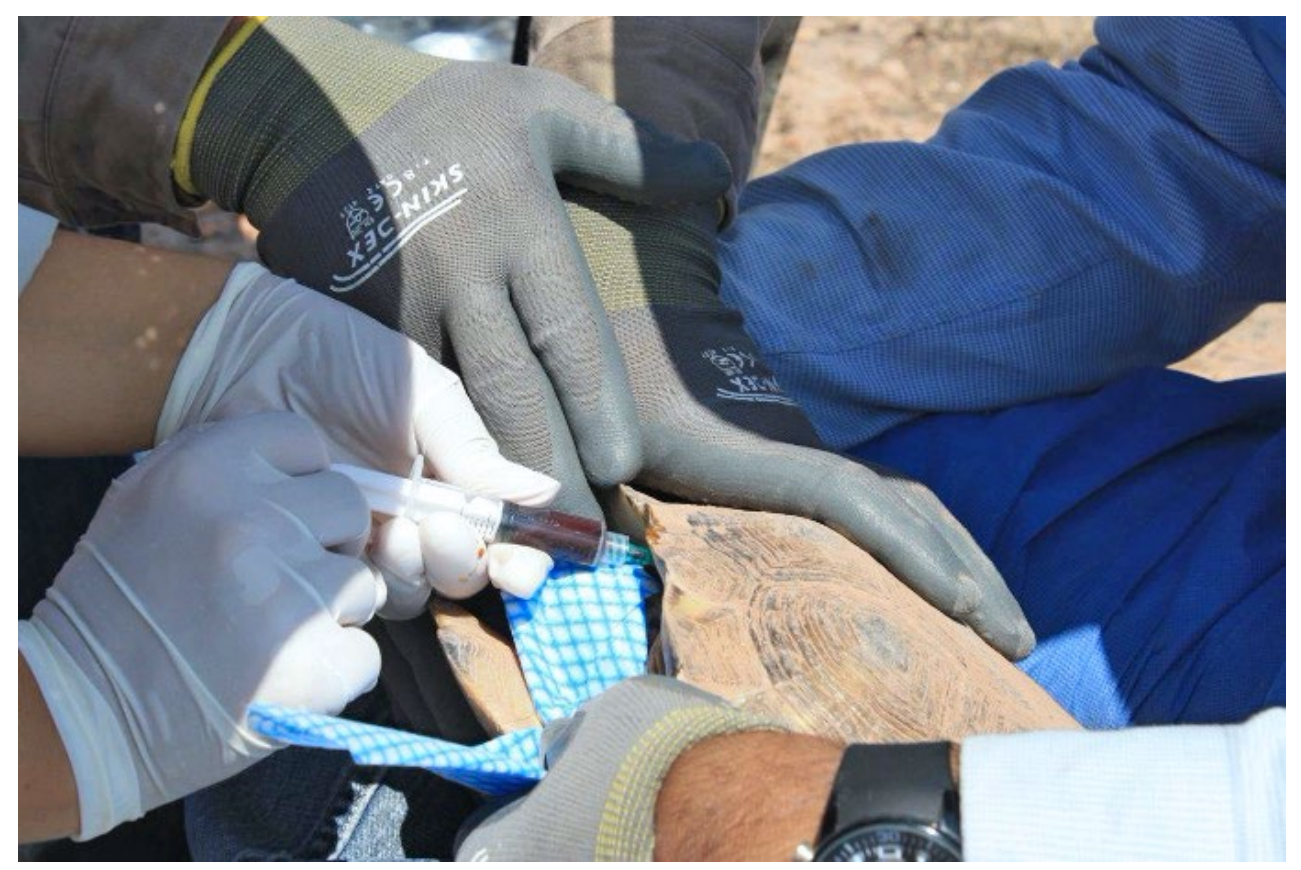

Figure 1. Blood collection from the subcarapacial vein in a Gopherus flavomarginatus tortoise.

Tortoise samples were collected under the DGVS 07249/15-16-17 permit granted by SEMARNAT, Mexico.

\section{Cell morphometry}

Blood samples were processed within the first three hours of collection. Two smears from each sample were prepared on glass slides and stained with Wright's dye (Analytyka $\left.{ }^{\circledR}\right)$. Blood cell types of $G$. flavomarginatus were characterized following criteria previously set for reptiles. 5,6,20-22 The center of the smear was chosen for observation of cell characteristics since it was where cells appeared in well-defined monolayers. ${ }^{23}$ Shape and color of cells were recorded by means of an Axiocam ERc5s Carl Zeiss $®$ microscope and camera. One hundred erythrocytes, 30 heterophils, 30 eosinophils, 30 basophils, 30 lymphocytes, 30 monocytes and 30 thrombocytes were measured for each gender. Cell length $(\mathrm{CL})$ and width (CW) were recorded for erythrocytes, heterophils, eosinophils, monocytes and thrombocytes, as well as the length and width of their nuclei (NL and NW, respectively). For basophils and lymphocytes, only length and width of cells were documented. All measurements were determined with the ImageTool 3.0 software, and total cell size $\left(\mu \mathrm{m}^{2}\right)$ was calculated using the formula (length $\left.\times A \times \varpi\right) / 4.24$

\section{Statistical analyses}

Normality and homoscedasticity of data were assessed by the Shapiro-Wilk and Levene tests, respectively $(P<0.05)$. The $x^{\prime}=\log (x+1)$ transformation was used when needed. ${ }^{25}$ Student $t$ tests were used to determine independent variable differences between gender $(P<0.05)$. Statistical tests were performed with the PAST 3.14 software. ${ }^{26}$ 


\section{Results and discussion}

Blood samples were obtained from forty-four $G$. flavomarginatus individuals (16 males, 28 females). Sizes found for all blood cells fell within previously documented values for reptiles.6,30 The shape and color of erythrocytes, leukocytes and thrombocytes of $G$. flavomarginatus were similar to those described for $G$. agassizii, and G. polyphemus tortoises.20,27-29 Erythrocytes showed an elliptical shape and smooth edges, with a central oval-shaped nucleus (Figure 2). The cytoplasm, which occupied a large surface area when compared to the nucleus, showed an acidophilic coloration (pink color), whilst the nucleus was dyed deep purple. Size of erythrocytes was similar between females $\left(216.06 \pm 24.0 \mu \mathrm{m}^{2}\right)$ and males $\left(215.46 \pm 24.2 \mu \mathrm{m}^{2}\right)(P=0.862 ;$ Table 1$)$. Nuclear size of erythrocytes was also analogous for both sexes $\left(19.96 \pm 5.1 \mu \mathrm{m}^{2}\right.$, and $18.95 \pm 4.8 \mu \mathrm{m}^{2}$, for females and males, respectively) ( $P=0.156$; Table 1). Most of the erythrocytes observed in the slides were mature and presented with the previously described morphology, however, larger round polychromatophilic cells were also apparent (Figure 2). Alleman et al. described polychromatophilic erythrocytes in G. agassizii tortoises. ${ }^{20}$ Indeed, this type of cell, albeit circulating in low quantities $(<1 \%)$, appears to be commonly found in healthy reptiles, particularly in juvenile or molting individuals. ${ }^{6}$

Granular leukocytes: heterophils, eosinophils, and basophils were also observed in smears. Heterophils showed a spherical shape with a large quantity of round and rod-like cytoplasmic granules that stained orange-pink. The lilac colored nucleus was round or oval, and eccentrically located (Figure 2). Sizes of these cells and their nuclei were similar for both males and females (heterophil cell size: $223.79 \pm 47.5 \mu \mathrm{m}^{2}$ in females, and $219.82 \pm 49.5 \mu \mathrm{m}^{2}$ in males, $P=0.753$, heterophil nuclear size: $223.79 \pm 47.5 \mu \mathrm{m}^{2}$ in females, and $219.82 \pm 49.5 \mu \mathrm{m}^{2}$ in males, $P=0.864$; Table 1). While the morphology and coloration of eosinophils were similar to that seen for heterophils, the cytoplasmic granules in the former cells were completely spherical (Figure 2). Eosinophil cell and nuclei sizes were comparable between sexes (cell size: $216.80 \pm 26.7 \mu \mathrm{m}^{2}$ in females and 217.51 $\pm 38.6 \mu \mathrm{m}^{2}$ in males, $P=0.934$; nuclear size: $45.24 \pm 10.1 \mu \mathrm{m}^{2}$ in females and $41.24 \pm 10.5 \mu \mathrm{m}^{2}$ in males, $P=0.138$; Table 1). Round-shaped basophils had a large number of intensely basophilic (purple) cytoplasmic granules that mostly covered the nucleus completely. When the nucleus was visible, it was round and either central or eccentric (Figure 2). Degranulated basophils could also be detected in blood smears. No differences in basophil morphometry were found between sexes (cell size: $99.66 \pm 26.1 \mu \mathrm{m}^{2}$ in females and $108.56 \pm 20.4 \mu \mathrm{m}^{2}$ in males, $P=$ 0.147; Table 1). The morphological similarity between heterophils and eosinophils is well-known for most reptile species, and it is the differences of their cytoplasmic granule shapes that allows for the differentiation between both cell types. ${ }^{30}$ Accordingly, heterophil granules were rod-like shaped, while eosinophil granules were round in G. flavomarginatus smears.

The detected non-granular leukocytes were lymphocytes and monocytes. Lymphocytes were characterized by being round-shaped, with a pink stained cytoplasm, and a large pale purple nucleus that occupied most of the cell (Figure 2). No gender differences were observed for lymphocyte size (49.04 $\pm 16.2 \mu \mathrm{m}^{2}$ in females, and $42.88 \pm 9.2 \mu \mathrm{m}^{2}$ in males, $(P=0.075$; Table 1). Monocytes had a round or amoeboid shapes and a pleomorphic nucleus (which could be round, oval, kidney-shaped or lobed). Both the cytoplasm and the nucleus stained pale pink, 


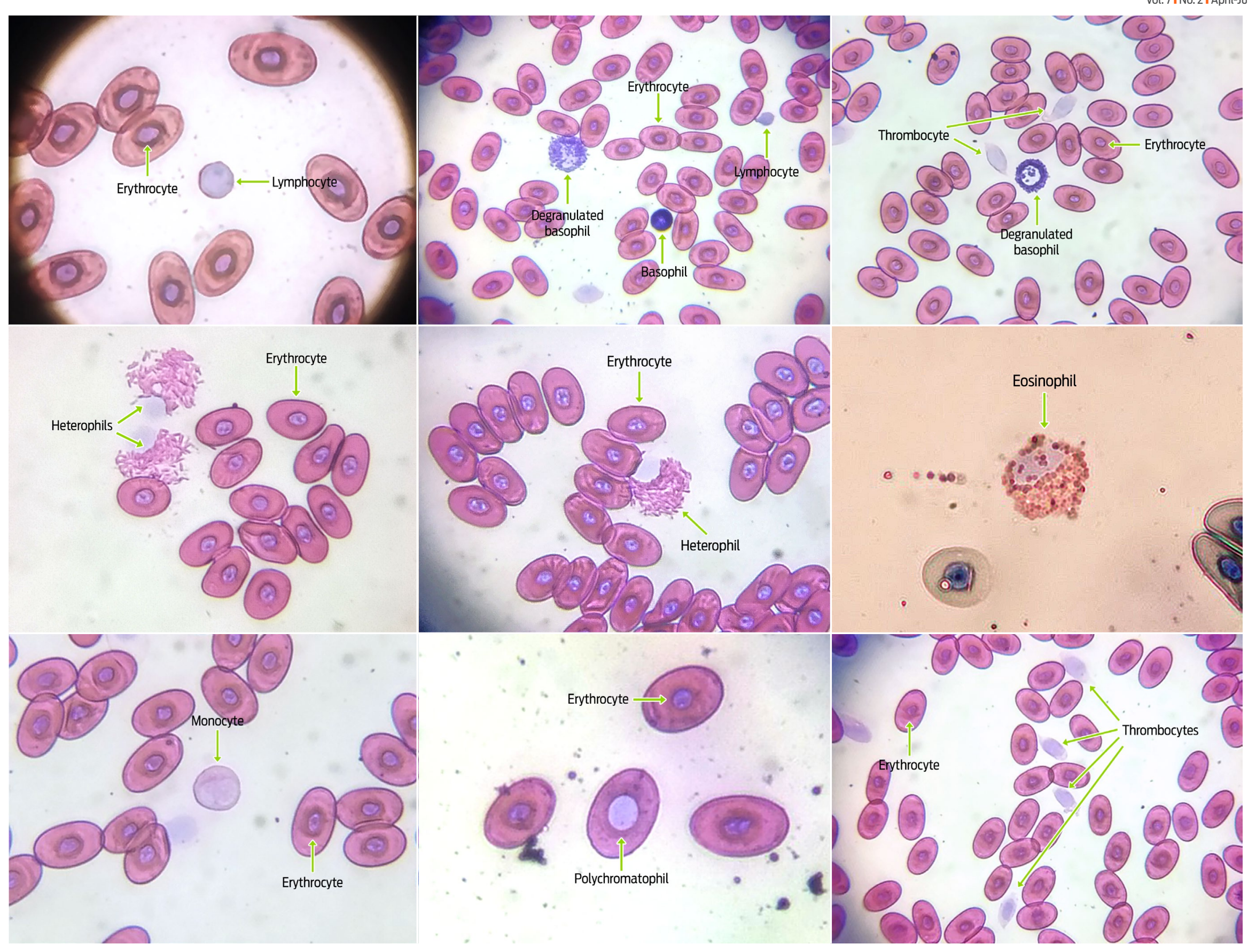


Table 1. Length and width of blood cells $\left(\mu \mathrm{m}^{2}\right)$ in male and female Gopherus flavomarginatus tortoises.

\begin{tabular}{|c|c|c|c|c|c|c|c|c|}
\hline Gender & Measurement & Erythrocyte & Heterophil & Eosinophil & Basophil & Lymphocyte & Monocyte & Thrombocyte \\
\hline \multirow{2}{*}{ Male } & $\mathrm{CL}$ & $21.6 \pm 1.0$ & $17.7 \pm 2.0$ & $17.6 \pm 1.4$ & $11.7 \pm 1.1$ & $7.4 \pm 0.8$ & $16.7 \pm 2.0$ & $10.5 \pm 1.0$ \\
\hline & $\mathrm{CW}$ & $12.3 \pm 0.9$ & $15.6 \pm 2.2$ & $15.6 \pm 2.2$ & $11.6 \pm 1.1$ & $7.3 \pm 0.8$ & $15.4 \pm 2.4$ & $9.6 \pm 1.2$ \\
\hline & $\mathrm{NL}$ & $6.0 \pm 0.8$ & $7.8 \pm 1.1$ & $8.3 \pm 1.4$ & - & - & $10.2 \pm 2.2$ & $6.9 \pm 1.1$ \\
\hline \multirow{2}{*}{ Female } & $\mathrm{NW}$ & $4.5 \pm 0.6$ & $6.3 \pm 0.9$ & $6.2 \pm 0.9$ & - & - & $7.6 \pm 1.7$ & $5.1 \pm 0.8$ \\
\hline & $\mathrm{CL}$ & $22.4 \pm 1.5$ & $17.8 \pm 1.8$ & $17.6 \pm 1.0$ & $11.1 \pm 1.1$ & $7.8 \pm 1.3$ & $17.0 \pm 1.9$ & $10.6 \pm 1.1$ \\
\hline & $\mathrm{CW}$ & $12.5 \pm 1.0$ & $15.8 \pm 2.0$ & $15.6 \pm 1.7$ & $11.1 \pm 1.4$ & $7.7 \pm 1.2$ & $15.3 \pm 2.2$ & $9.5 \pm 1.1$ \\
\hline & $\mathrm{NL}$ & $5.7 \pm 0.6$ & $7.7 \pm 1.0$ & $8.8 \pm 1.3$ & - & - & $10.3 \pm 2.2$ & $7.0 \pm 1.0$ \\
\hline
\end{tabular}

CL: cell length; CW: cell width; NL: nucleus length; NW: nucleus width. Data are presented as mean \pm standard deviation.

with the latter being paler than the former (Figure 2). No differences were found for monocyte cell or nuclear sizes between sexes (cell size: $207.66 \pm 43.0 \mu \mathrm{m}^{2}$ in females, and $204.47 \pm 43.3 \mu \mathrm{m}^{2}$ in males, $P=0.776$; Nuclear size: $62.0 \pm$ $15.5 \mu \mathrm{m}^{2}$ in females, $60.87 \pm 15.6 \mu \mathrm{m}^{2}$ in males, $P=0.780$, Table 1). Monocytes were the scarcest type of leukocytes in G. flavomarginatus blood smear samples, and were characterized as type 1 monocytes. Conversely, there are two types of monocytes that can be found in Gopherus agassizii tortoises: type 1 is the most abundant and its morphology is very similar to that found in mammals, with a single irregularly shaped nucleus, moderate amounts of cytoplasm (of a pale pink tone) and one or more light colored vacuoles; type 2 monocytes are similar to type 1 but the nucleus is lobed or pleomorphic, with small amounts of small cytoplasmic granules of a reddish purple coloration, which is why they are called azurophil monocytes. ${ }^{20}$ These latter cells are rare in chelonians, but common in snakes, lizards and crocodiles, where they contribute to inflammatory reactions. 6,28,31

Finally, thrombocytes were found to have an oval or round shape. The nucleus was ellipsoid and stained either pink or light purple. The cytoplasm was observed surrounding the nucleus, with bright hyaline material (Figure 2). Thrombocyte morphology was similar for males and females of the G. flavomarginatus species (cell size: $79.96 \pm 13.7 \mu \mathrm{m}^{2}$ in females, and $79.97 \pm 15.7 \mu \mathrm{m}^{2}$ in males, $P=0.998$; nuclear size: $27.38 \pm 5.2 \mu \mathrm{m}^{2}$ in females and $28.18 \pm 6.6 \mu \mathrm{m}^{2}$ in males, $P=0.602$; Table 1). Most thrombocytes were easily recognized because they tended to agglutinate, however, when observed individually, a transparent, even shiny, cytoplasm with spike-like extensions could be seen. Similar characteristics have been previously described for $G$. agassizii thrombocytes. ${ }^{20}$

\section{Conclusions}

This work describes the blood cell morphology of wild Bolson tortoises in the Mexican Chihuahuan desert. The data obtained from this study advances the knowledge of the biological traits of G. flavomarginatus, and is thus instrumental towards efforts to monitor the health status of captured individuals, as well as for the development of conservation strategies aimed to protect this endangered species. 


\section{Funding}

This work was supported by CONACYT Ciencia Básica (Project No. 220658).

\section{Acknowledgements}

Authors wish to thank Magdalena Rivas-García, Nohemí Villa-Vázquez, Estefanía Garduño-Niño, Mirsha Rojas-Domínguez, Romario Martínez-Saldívar, Jesús Martínez-Luna, Ricardo Zapata-Ramírez, Irene Pacheco-Torres, and Sergio Barraza-Guerrero for their help in the field work. Thanks also go to Cristino Villarreal-Wislar and the personnel of the Mapimí Biosphere Reserve for logistic support throughout this study. Finally, thanks to Nicole Stacy (University of Miami) for her support in blood cell determinations and Cameron W. Barrows (University of California, Riverside) for the English review.

\section{Conflicts of interest}

The authors declare no conflicts of interest.

\section{Author contributions}

C. G. de la P., R. I. R.-V. and J. A. Z.-D. designed the study, analyzed data and wrote the manuscrip; L. M. V.-N., C. A. M.-H. and Q. S.-R. revised the final version of the manuscript.

\section{References}

1. Campbell TW. Hematology of lower vertebrates. In: ASVCP, ACVP, ASVCP, editors. 55th Annual Meeting of the American College of Veterinary Pathologists (ACVP) \& 39th Annual Meeting of the American Society of Clinical Pathology. Middleton Wl; 2004. p. 1103-214.

2. Tavares-Dias M, Oliveira-Junior AA, Silva MG, Marcon JL, Barcellos JFM. Comparative hematological and biochemical analysis of giant turtles from the Amazon farmed in poor and normal nutritional conditions. Vet Arh. 2009;79:601-10.

3. Knotkova Z, Mazanek S, Hovorka M, Sloboda M, Knotek Z. Haematology and plasma chemistry of Bornean River turtles suffering from shell necrosis and haemogregarine parasites. Vet Med Czech. 2005;50(9):421-6.

4. Joyner PH, Shreve AA, Spahr J, Fountain AL, Sleeman JM. Phaeohyphomycosis in a free-living eastern box turtle (Terrapene carolina carolina). J Wildl Dis. 2006;42(4):883-8.

5. Irizarry-Rovira AR. Hematology of reptiles. In: Weiss DJ, Wardrop KJ, editors. Schalm's veterinary hematology. Ames, IA: Wiley-Blackwell; 2010. p. 1004-12.

6. Stacy NI, Alleman AR, Sayler KA. Diagnostic hematology of reptiles. Clin Lab Med. 2011;31:87-108.

7. Campbell TW. Exotic animal hematology and cytology. 4th ed. Oxford, UK: Wiley Blackwell; 2015.

8. Morafka DJ, Aguirre G, Adest GA. Gopherus flavomarginatus Bolson Tortoise. In: Swingland R, Klemens MW, editors. The conservation biology of tortoises. Gland, Switzerland: Occasional Papers of the IUCN Species survival Commission (SSC) No. 5. IUCN; 1989. p. 10-13.

9. SEMARNAT. NORMA Oficial Mexicana NOM-059-SEMARNAT-2010, Protección ambiental-Especies nativas de México de flora y fauna silvestres-Categorías de 
riesgo y especificaciones para su inclusión, exclusión o cambio-Lista de especies en riesgo. Mexico: Diario Oficial; 30 diciembre 2010.

10. Kiester AR, Palomo-Ramos R, Ríos-Arana J, Goode EV. Gopherus flavomarginatus. The IUCN Red List of Threatened Species [Internet]. 2018; e.T9402A1 12660985. http://dx.doi.org/10.2305/IUCN.UK.2018-2.RLTS.T9402A 1 12660985.en

11. CONANP. Programa de Conservación y Manejo Reserva de la Biosfera Mapimí México. Mexico: CONANP-SEMARNAT; 2006.

12. Carlson JE, Menges ES, Marks PL. Seed dispersal by Gopherus polyphemus at Archbold Biological Station, Florida. Fla Sci. 2003;66(2):147-54.

13. Jackson D, Milstrey EG. The fauna of gopher tortoise burrows. In: Diemer J, Jackson D, Landers L, Layne J, Wood D, editors. Proceedings of the Gopher Tortoise Relocation Symposium. Tallahassee, Florida. Florida Game and Freshwater Fish Comm. Nongame Wildlife Program, Technical Report No. 5; 1989. p. 86-98.

14. Lips KR. Vertebrates associated with tortoise (Gopherus polyphemus) burrows in four habitats in south-central Florida. J Herpetol. 1991;25(4):477-81.

15. García E. Modificaciones al sistema de clasificación climática de Koppen. Serie Libros Número 6. 5th ed. Mexico: Instituto de Geografía Universidad Nacional Autónoma de México; 2004.

16. Rzedowski, J. Vegetación de México. 1st ed. Mexico: Comisión Nacional para el Conocimiento y Uso de la Biodiversidad; 2006.

17. USFWS. Health assessment procedures for the desert tortoise (Gopherus agassizii): A handbook pertinent to translocation. U.S. Fish and Wildlife Service, Desert Tortoise Recovery Office, Reno, Nevada, USA [Internet]. 2016. Available at: https://www.fws.gov/nevada/desert_tortoise/documents/reports/2016/may2016-desert-tortoise-health-eval-handbook.pdf

18. Adest GA, Aguirre-Leon G, Morafka DJ, Jarchow JV. Bolson tortoise (Gopherus flavomarginatus) conservation: I. Life history. Vida Silvestre Neotrop. 1989;2:7-13.

19. Jacobson ER. Health issues of North American tortoises. In: Rostal DC, McCoy ED, Mushinsky HR, editors. Biology and conservation of North American tortoises. Baltimore, MD: Johns Hopkins University Press; 2014. p. 60-76.

20. Alleman AR, Jacobs ER, Raskin RE. Morphologic and cytochemical characteristics of blood cells from the desert tortoise (Gopherus agassizii). Am J Vet Res. 1992;53(9):1645-51.

21. Barrows M, McArthur S, Wilkinson R. Diagnosis. In: McArthur S, Wilkinson R, Meyer J, editors. Medicine and surgery of tortoises and turtles. Oxford, UK: Blackwell Publishing; 2004. p. 109-140.

22. Thrall MA, Baker DC, Campbell TW, DeNicola D, Fettman MJ, Lassen ED, Rebar A, Weiser G. Veterinary hematology and clinical chemistry. Ames IA: Blackwell Publishing; 2006.

23. Harvey J. Atlas of veterinary hematology: blood and bone marrow of domestic animals. Hong Kong: Saunders; 2001.

24. Metin K, Turkozan O, Kargin F, Koca YB, Taskavak E, Koca S. Blood cell morphology and plasma biochemistry of the captive European pond turtle Emys orbicularis. Acta Vet Brno. 2006;75:49-55.

25. Zar JH. Bioestadistical analysis. 4th ed. Upper Sandle River, NJ: Prentice Hall; 1999.

26. Hammer Ř, Harper DAT, Ryan PD. PAST: Paleontological Statistics Software package for education and data analysis. Palaeontol Electron. 2001;4(1):9. 
27. Diaz-Figueroa O. Characterizing the health status of the Louisiana Gopher tortoise (Gopherus polyphemus) [PhD thesis]. Baton Rouge, LA: Louisiana State University and Agricultural and Mechanical College; 2005.

28. Strik NI, Alleman AR, Harr KE. Circulating inflammatory cells. In: Jacobson ER, editor. Infectious diseases and pathology of reptiles. Boca Raton, FL: CRC Press; 2007. p. 167-218.

29. Kirchgessner M, Mitchell MA. Chelonians. In: Mitchell MA, Tully TN, editors. Manual of exotic pet practice. Philadelphia, PA: Saunders, Elsevier; 2009. p. 200-80.

30. Arikan H, Cicek K. Haematology of amphibians and reptiles: a review. NorthWest J Zool. 2014;10(1):190-209.

31. Nardini G, Leopardi S, Bielli M. Clinical hematology of reptilian species. Vet Clin North Am Exot Anim Pract. 2013;16(1):1-30. 